\title{
MODEL LATIHAN INKUIRI (MLI) DIPADU PETA KONSEP PADA PERKULIAHAN BIOLOGI UMUM UNTUK MENINGKATKAN KEMAMPUAN BERPIKIR SISTEM MAHASISWA CALON GURU BIOLOGI
}

\author{
Sri Sujayanty ${ }^{1,2}$ \\ Fransisca. S Tapilouw ${ }^{3}$ \\ Sri Redjeki ${ }^{3}$ \\ ${ }^{1}$ Science Education Program, Graduate School of Indonesia University of Education \\ ${ }^{2}$ FKIP University of Quality Medan \\ ${ }^{3}$ Department of Biology Education, FPMIPA UPI \\ e-mail:Jayenti_mdn@yahoo.com
}

\begin{abstract}
Abstrak: Keterampilan berpikir yang efektif merupakan suatu karakteristik penting di sekolah pada setiap jenjangnya. Mengajarkan keterampilan berpikir secara eksplisit, memadukannya dengan materi pembelajaran (kurikulum) dan melakukan assessment berpikir tingkat tinggi dapat membantu mahasiswa untuk menjadi pemikir yang kritis dan kreatif secara efektif. Kemampuan berpikir seperti berpikir sistem jarang diajarkan secara khusus dan terpisah oleh dosen di kelas. Mengajarkan kemampuan berpikir secara eksplisit dengan memadukannya pada materi perkuliahan akan membantu mahasiswa calon guru Biologi menjadi pemikir yang efektif. Upaya untuk meningkatkan kemampuan berpikir sistem calon guru Biologi dapat dilakukan dengan menyesuaikan materi perkuliahan Biologi Umum dengan model pembelajaran yang dapat meningkatkan kemampuan berpikir sistem, antara lain yang dikemas dalam bentuk model latihan Inkuri dipadukan dengan peta konsep. Hasil analisis menunjukkan kemampuan berpikir sistem mahasiswa calon guru Biologi setelah mengikuti perkuliahan menggunakan MLI dipadu peta konsep pada materi Pencemaran udara rata rata 70,33 dikategorikan cukup, persentasi pencapaian indikator kemampuan berpikir sistem rata rata 74,33\% dikategorikan baik, penguasaan konsep mahasiswa pada materi pencemaran udara rata rata 66,10 dikategorikan baik, korelasi antara penguasaan konsep dan kemampuan berpikir sistem (r) 0.9753 menunjukan korelasi tinggi.
\end{abstract}

Kata kunci : Model Latihan Inkuri, Peta Konsep, Perkuliahan Biologi Umum, Berpikir sistem.

\begin{abstract}
An effective thinking skill, which is considered as an important characteristic, is needed for all grades at school. Teaching thinking skill, blending thinking skill and teaching materials (curriculum) and assesing of higher order thinking can help student to be an effective critical and creative thinker. The lecture is seldon teach about thinking, such as system thinking. Teaching thinking skill explicitly through lecturing content material could help student of Biology teacher to be effective thinker in the future. In order to improve the thinking ability of the student of Biology teacher, it could be through implementing an appropriate model of teaching such as Inquiry Training Model (ITM) combined with concept mapping. Result shown that it is about 70,33 of biology teacher candidate students are in a enough category of sistem thinking ability after following blended Inquiry Training Model (ITM) and concept mapping on general biology instruction, the achievement of indicator system thinking students was categorized good, student's understanding about air pollution was categorized good, the correlation between student's understanding and system thinking shows high correlation.
\end{abstract}

Keywords : Inquiry Training Model, Concept Mapping, General Biology Instruction, System Thinking

\section{PENDAHULUAN}

Kemampuan berpikir yang efektif merupakansuatu hal yang dianggap penting di sekolah pada setiap jenjangnya, meskipun kemampuan berpikir tersebut jarang diajarkan secara khusus dan terpisah oleh dosen di kelas. Mengajarkan kemampuan berpikir secara eksplisit dengan memadukannya pada materi pembelajaran (kurikulum) akan dapat membantu mahasiswa untuk menjadi pemikir yang efektif. Melalui perkuliahan Biologi Umum diharapkan dapat member kontribusi dalam mengembangkan kemampuan berpikir diantaranya adalah berpikir sistem untuk mahasiswa calon guru. Hal tersebut sesuai dengan hasil penelitian yang dilakukan Werner, $\mathrm{R}$ \& Christoph, M. (2010), bahwa berpikir sistem dapat diperkenalkan melalui pembelajaran Biologi.

Kemampuan berpikir sistem adalah kemampuan yang dimiliki seseorang untuk melihat suatu permasalahan secara menyeluruh dalam suatu sistem, sehingga dalam mengambil suatu kesimpulan untuk mempertimbangkan hubungan antar komponen satu dengan yang lain yang menunjuk suatu hasil secara keseluruhan. Kemampuan berpikir sistem mahasiswa dapat diuraikan berdasarkan ketercapaian indikator kemampuan berpikir sistem yang dicapai mahasiswa dalam menyelesaikan suatu permasalahan yang diberikan terkait dengan materi perkuliahan Biologi Umum. Kemampuan ini pada mahasiswa calon guru perlu dikembangkan, karena dengan kemampuan berpikir sistem yang baik, seseorang 
dapat menganalisis setiap masalah dalam penugasan yang diberikan secara efektif dan efisien. Dengan berpikir sistem seseorang akan mampu melihat setiap masalah secara struktural sehingga mampu melihat dan menemukan akar masalah secara obyektif dan akurat.

Aktivitas dan proses berpikir akan terjadi apabila seorang berhadapan dengan suatu situasi atau masalah yang mendesak dan menantang serta dapat memicunya untuk berpikir agar diperoleh kejelasan dan solusi atau jawaban terhadap masalah yang dimunculkan dalam situasi yang dihadapinya. Salah satu upaya yang dapat dilakukan untuk membantu mengatasi permasalahan siswa dalam memecahkan masalah perlu dikembangkan learning how to learn yaitu dengan system thinking approach dan penggunaan peta konsep terhadap anak sejak dini (Liwatimena, 2008). Keterampilan berpikir dapat dilatihkan oleh dosen kepada mahasiswa melalui skenario pembelajaran tertentu Salah satu strategi yang dapat dilakukan dosen dalam pembelajaran yaitu dengan memberikan materi yang tidak terlalu banyak tetapi mendalam, karena tujuan belajar bukanlah mengakumulasikan dari berbagai fakta, tetapi kemampuan untuk menggunakan sejumlah kecil pengetahuan dasar untuk memprediksi atau menjelaskan beragam fenomena, sehingga mahasiswa mendapatkan manfaat dari pengetahuan yang diingat dan dipahaminya.

Skenario pembelajaran yang dapat diberikan pada perkuliahan Biologi Umum dalam upaya meningkatkan kemampuan berpikir sistem mahasiswa calon guru Biologi adalah dengan menggunakan Model Latihan Inkuiri yang dipadukan dengan peta konsep.

Indikator dari berpikir sistem meliputi kemampuan:

1. Mengidentifikasi komponen dan proses sistem yang terdapat di dalamnya

2. Mengidentifikasi hubungan antara komponen system

3. Mengelompokkan komponen dan proses yang ada didalam suatu kerangka hubungan

4. Membuat generalisasi

5. Berpikir temporer dan membuat prediksi

6. Mengidentifikasi hubungan timbale balik setiap komponen dalam system

7. Mengidentifikasi akibat yang timbul apabila sebuah komponen dalam sistem tersebut tidak berfungsi. ( Orit Ben-Zvi \& Nir Orion, 2005, Evagorou , 2009)

Desain perkuliahan MLI yang dipadukan peta konsep terdiri dari tahapan tahapan seperti pendahuluan dengan menjelaskan mekanisme perkuliahan model latihan inkuiri (MLI) dipadu peta konsep, kemudian membagi mahasiswa dalam kelompok yang dilanjutkan menunjuk notulis pada setiap kelompok. Tahapan berikutnya memberikan masalah yang memancing mahasiswa untuk bertanya, mengadakan tanya jawab dimana dosen menjawab dengan "ya" atau "tidak". Dari hasil tanya jawab mahasiswa dan dosen, mahasiswa membuat peta konsep serta menjawab LKM, kemudian mahasiswa diberi kesempatan memaparkan apa yang dituangkan dalam peta konsep terkait masalah yang diajukan, setelah itu menganalisis strategi berpikir sistem dengan mengumpulkan pertanyaan yang diajukan dan peta konsep yang dibuat. Akhir dari perkuliahan sebagai penutup adalah merangkum hasil tanya jawab dan diskusi.

\section{METODE PENELITIAN}

Penelitian ini merupakan penelitian weak eksperiment. Populasi penelitian adalah seluruh mahasiswa semester satu jurusan pendidikan Biologi Universitas Kuningan yang mengikuti perkuliahan Biologi umum. Sampel yang digunakan dalam penelitian ini sebanyak 16 orang mahasiswa semester satu yang mengikuti perkuliahan Biologi Umum Jurusan Pendidikan Biologi FKIP Universitas Kuningan. Penelitian ini dilaksanakan bulan November 2012. Setelah mahasiswa diberikan perkuliahan Biologi Umum menggunakan MLI dipadu peta konsep pada materi pencemaran udara diberikan evaluasi untuk melihat penguasaan konsep, kemampuan berpikir sistem serta hubungan antara penguasaan konsep dengan kemampuan berpikir sistem mahasiswa.

\section{HASIL DAN PEMBAHASAN}

Tes yang diberikan sebanyak 12 butir soal, dengan perincian 10 soal tes pilihan ganda dan 2 butir soal essay. Kedua belas butir soal tersebut mencakup indikator kemampuan berpikir sistem, yang terdiri dari 7 (tujuh) indikator. Hasil analisis Kemampuan berpikir sistem mahasiswa pada materi pencemaran udara seperti ditunjukan pada Tabel 1.

Tabel 1 : Skor Kemampuan berpikir Sistem Mahasisw a

\begin{tabular}{ccl}
\hline No. Mahasiswa & $\begin{array}{c}\text { Skor Kemampuan Berpikir } \\
\text { sistem }\end{array}$ & \multicolumn{1}{c}{ Kategori } \\
\hline 1 & 69.00 & Cukup \\
2 & 69.00 & Cukup \\
3 & 83.23 & Baik \\
4 & 71.37 & Cukup \\
5 & 97.51 & Sangat baik \\
6 & 88.03 & Baik \\
7 & 90.43 & Sangat baik \\
8 & 64.23 & Cukup \\
9 & 50.00 & Kurang \\
10 & 38.09 & Kurang \\
11 & 57.14 & Cukup \\
12 & 42.86 & Kurang \\
13 & 71.37 & Cukup \\
14 & 83.23 & Baik \\
\hline
\end{tabular}




\begin{tabular}{|c|c|c|}
\hline No. Mahasiswa & $\begin{array}{c}\text { Skor Kemampuan Berpikir } \\
\text { sistem }\end{array}$ & Kategori \\
\hline 15 & 64.23 & Cukup \\
\hline 16 & 85.60 & Baik \\
\hline Rerata & 70,33 & Cukup \\
\hline $\begin{array}{l}\text { Kriteria : } \\
89,02-100 \\
72,05-89,02 \\
55,07-72,04 \\
38,09-55,06\end{array}$ & $\begin{array}{l}\text { Sangat baik } \\
\text { Baik } \\
\text { Cukup } \\
\text { kurang }\end{array}$ & \\
\hline
\end{tabular}

Kemampuan berpikir sistem mahasiswa rerata 70,33 dikategorikan cukup, dengan perincian kategori sangat baik ada 2 orang atau 12,50\%, kategori baik 4 orang atau 25,00\%, kategori cukup 7orang atau 43,75\% dan kategori kurang 3 orang atau 18,75\%, secara rinci dapat dilihat pada Gambar 1.

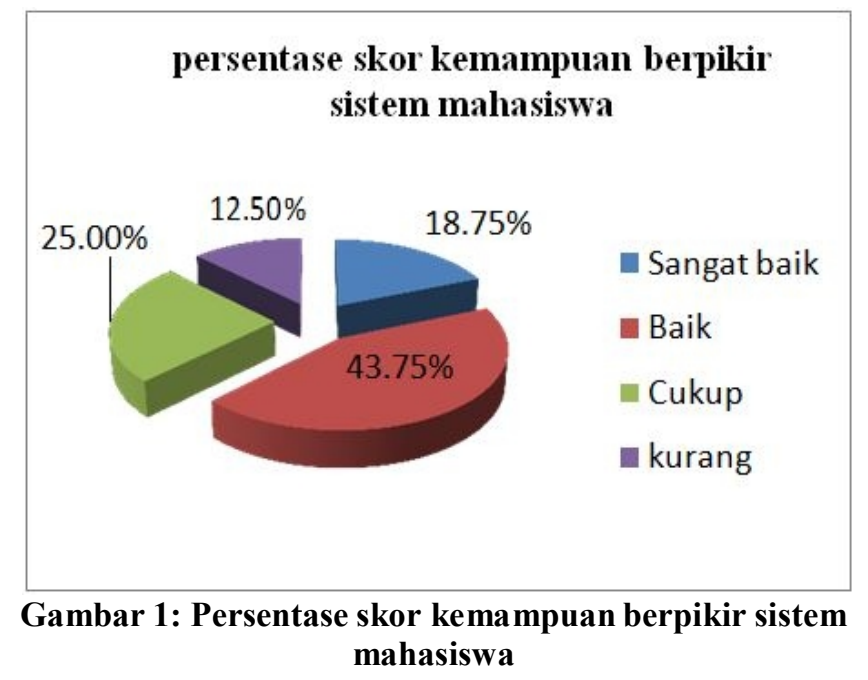

Kemampuan berpikir sistem ditinjau dari ketercapaian 7 (tujuh) indikator, persentase ketercapaiann untuk setiap indicator berpikir sistem seperti pada Tabel 2.

Tabel 2: Ketercapaian indilikator berpilir sistem maluasiswa

\begin{tabular}{|c|c|c|}
\hline Indikator Bervikirir Sistem & $\begin{array}{c}\text { Ketercapaian } \\
(\%)\end{array}$ & Kategogori \\
\hline 1. Mengidentifikasi Komponen & 100 & Sangatbaik \\
\hline $\begin{array}{l}\text { 2. Mengububunglan komponend dalam sistem } \\
\text { Dalam suatukerangkka hubungann }\end{array}$ & 45,31 & Kurang \\
\hline 4. Membuat generalisasi & 43,75 & Kurang \\
\hline 5. Berpikit temporer dan membuatprediliksi & 81,25 & Baik \\
\hline $\begin{array}{l}6 \text { Mengidentifikasi hubungan timbal balik setiap komponen dalam } \\
\text { sistem }\end{array}$ & 87,50 & Baik \\
\hline $\begin{array}{l}\text { 7. Mengidentifikasi akibat yang muncul apabila salah satu kompoen } \\
\text { dalam sistem tidalkberfungsi }\end{array}$ & 93,75 & SangatBaik \\
\hline Rerata & 74,33 & Baik \\
\hline
\end{tabular}

Kriteria:

$43,75 \% \cdot 58,39 \%$ Kurang

$58,40 \% \cdot 73,02 \%$ Culkup

$73,03 \% \cdot 87,65 \%$ Baik

$87,66 \% \cdot 100 \%$ Sangatbaik
Dari data tersebut diketahui kemampuan mahasiswa dalam mengidentifikasi komponen dan mengidentifikasi akibat yang muncul apabilah salah satu komponen sangat baik. Kemampuan mengidentifikasi hubungan timbal balik setiap komponen serta berpikir temporer dan membuat prediksi termasuk kategori baik. Kemampuan dalam mengelompokan komponen dan proses dalam suatu kerangka hubungan termasuk kategori cukup, sedangkan kemampuan mengidentifikasi hubungan antar komponen serta membuat generalisasi masih kurang. Dari gambaran rata rata kemampuan berpikir sistem mahasiswa termasuk kategori baik yaitu sebesar 74,33\%.

Penguasaan konsep mahasiswa Materi pencemaran udara setelah mengikuti perkuliahan menggunakan MLI dipadu dengan peta konsep seperti pada Tabel 3.

Tabel: 3 Skor Penguasaan konsep mahasiswa

\begin{tabular}{ccc}
\hline No Mahasiswa & $\begin{array}{c}\text { Skor Penguasaan } \\
\text { Konsep }\end{array}$ & Kategori \\
\cline { 2 - 3 } \cline { 3 - 3 } 2 & 64,29 & Cukup \\
2 & 64,29 & Cukup \\
3 & 78,57 & Baik \\
4 & 71,43 & Baik \\
5 & 85,71 & Sangat Baik \\
6 & 85,71 & Sangat Baik \\
7 & 78,57 & Baik \\
8 & 64,29 & Cukup \\
9 & 42,88 & Kurang \\
10 & 35,71 & Kurang \\
11 & 50,00 & Kurang \\
12 & 42,86 & Kurang \\
13 & 64,29 & Cukup \\
14 & 78,57 & Baik \\
15 & 64,29 & Cukup \\
16 & 85,71 & Sangat baik \\
\hline Rerata & 66,10 & Baik \\
\hline
\end{tabular}

Kriteria:

79,61 - 100 Sangat baik

$65,31-79,60 \quad$ Baik

$50,01-65,30 \quad$ Cukup

$35,71-50,00 \quad$ Kurang

Dari data tersebut penguasaan konsep mahasiswa jurusan pendidikan Biologi Universitas Kuningan setelah mengikuti perkuliahan Biologi Umum materi pencemaran udara termasuk kategori cukup dengan rerata nilai 66,10 , dengan perincian kategori penguasaan konsep sangat baik 3 orang atau $18,75 \%$, kategori baik 4 orang atau $25 \%$, kategori cukup 6 0rang atau 37,50\%, sedangkan penguasaan konsep mahasiswa dengan kategori kurang 3 orang atau $18,75 \%$, secara rinci persentasi penguasaan konsep mahasiswa pada materi pencemaran udara seperti pada Gambar 2. 


\section{Persentasi penguasaan Konsep Mahasiswa}

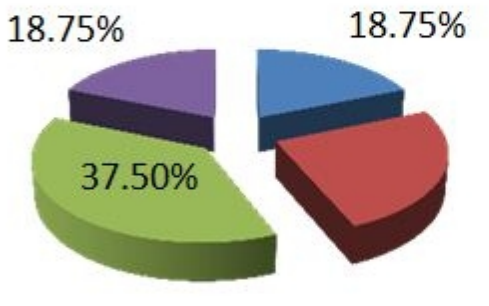

- Sangat Baik

Baik

Cukup

Kurang

$-25.00 \%$

Korelasi antara penguasaan konsep mahasiswa dengan kemampuan berpikir sistem diperoleh hasil $\mathrm{r}=$ 0,9753, hal ini menunjukan bahwa korelasinya sangat tinggi. Dengan demikian ada kaitan positif yang berarti antara penguasaan konsep dengan kemampuan berpikir sistem.

\section{SIMPULAN}

1. Kemampuan berpikir sistem mahasiswa pendidikan Biologi Universitas Kuningan setelah mengikuti perkuliahan Biologi Umum termasuk kategori cukup dengan rerata 70,33 .

2. Persentasi ketercapaian indikator kemampuan berpikir sistem mahasiswa pendidikan Biologi Universitas Kuningan setelah mengikuti perkuliahan Biologi Umum materi pencemaran udara termasuk kategori baik dengan rerata 74,33 .

3. Penguasaan konsep mahasiswa pendidikan Biologi Universitas Kuningan setelah mengikuti perkuliahan Biologi Umum materi pencemaran udara termasuk kategori baik dengan rerata nilai 66,10 .

4. Korelasi antara penguasaan konsep mahasiswa dan kemampuan berpikir sistem (r) $=0,9753$, hal ini menunjukan bahwa korelasi yang sangat tinggi.

\section{DAFTAR PUSTAKA}

Direktorat Jenderal Pendidikan Dasar dan Menengah, Depdikbud. (2000). PPPGIPA: Model-Model Pembelajaran. Bandung: Depdikbud.

Evagoroua,M., Korfiatis, K., Nicalaou, C., Constantinou, C. (2009). An Investigation of the Potential of Interactive Simulations for Developing System Thinking Skills in Elementary School: A case study with fifth-graders and sixth-graders. International Journal of Science Education Vol. 31.

Iman, S. M. (2008). Berpikir Serba-sistem dan Berpikir Strategik. [Online]. Tersedia: http://jiwafursan.multiply.com. [26 Maret 2008].
Teaching.Englewood Cliffs. New Jersey: Prentice Hall, Inc. Liwatimena, S. (2008). Mengapa Perlu Belajar Peta Konsep. [Online]. Tersedia : http://esmartschool.co.id . [7 januari 2008].

Orit Ben-Zvi Assaraf, Nir Orion. (2005). Development of System Thinking Skills in the Context of Earth System Education. Journal of Research in Science Teaching vol. 42.

Orit Ben-Zvi Assaraf, Nir Orion. (2010). System Thinking Skills at the Elementary School Level. Journal of Research in Science Teaching vol. 47.

Werner, R \& Christoph, M. (2010). Promoting Systems Thinking Through Biology Lessons. International Journal of Science Education Vol.32.

Joyce, B., and Weil. M. (1992). Models of 